\title{
KHAMAR DAN ALKOHOL; SEBUAH REKONSTRUKSI PEMAHAMAN ${ }^{\delta}$
}

\author{
Syaiful Rahmat Panggabean ${ }^{\circledR}$
}

\section{A. Pendahuluan}

Allah SWT telah memberikan segala macam bentuk nikmat, di antaranya nikmat jasmani dan nikmat rohani. Jika ditinjau dari segi jasmani, kita diperintahkan oleh Allah untuk makan dan minum dari hal yang baik-baik serta diperintahkan untuk menjauhkan dari hal yang kurang baik. Untuk menjaga kesehatan jasmani, kita harus menjauhkan diri dari segala makanan dan minuman yang dapat merusak sistem kekebalan tubuh di antaranya khamar.

Istilah 'khamar' yang diambil dari bahasa Arab yang diterjemahkan ke dalam bahasa Indonesia dengan kata 'arak' mengundang banyak kontroversi pemahaman tentang pengharaman jenis minuman dan zat lainnya yang dikonsumsi seperti tuak, ganja, shabu-shabu dan lain sebagainya. Hal ini disebabkan adanya penyempitan makna 'khamar' ketika diterjemahkan dengan kata 'arak' sedangkan kata 'tuak' dan zat yang lain tidak disebut dalam al-Quran.

Walaupun ada metode qiyas dalam pengambilan hukum syariat namun hal tersebut adalah merupakan hasil ijtihad ulama yang bersifat relatif (bisa benar dan bisa salah). Dengan demikian, ada beberapa golongan yang kurang memahami hal tersebut dan dengan selalu berpegang teguh terhadap apa yang termaktub dalam al-Quran dan sunnah dengan pernyataan bahwa yang haram adalah arak bukan tuak dan bukan ganja ataupun shabu-shabu.

Di sisi lain juga, pengharaman khamar terkadang membuat penyempitan hukum terhadap zat yang dikandung oleh khamar. Ketika khamar diharamkan, maka seluruh zat yang dikandung oleh khamar jadi haram adanya termasuk alcohol (etanol). Padahal khamar itu terdiri dari dari beberapa zat yang dapat dimanfaatkan demi kemaslahatan umat manusia.

\section{B. Makna Khamar}

Secara etimologi khamar diambil dari bahasa arab yaitu dari kata khamara (خمر) - yakhmuru atau yakhmiru ('خَخْرُ أو يَخْمِر) - khamran (خمرا') yang berarti tertutup, terhalang, atau tersembunyi. Dari kata inil pulalah diambil istilah untuk kain yang menutupi aurat wanita yakni khimar atau yang lebih sering disebut di Indonesia dengan istilah jilbab walaupun kedua penutup ini berbeda secara zahirnya.

Secara terminologi, khamar adalah segala sesuatu yang memabukkan dan dapat merusak akal, namun ulama figh berbeda-beda dalam memberikan definisi khamar. Jumhur ulama mengartikan khamar dengan "setiap minuman yang didalamnya terdapat zat yang memabukkan". Imam Hanafi menyatakan bahwa khamar adalah "sebagai nama (sebutan) untuk jenis minuman yang dibuat dari perasan anggur yang sudah dimasak sampai mendidih serta mengeluarkan buih dan kemudian menjadi bersih kemball".

Ada sebagian ulama yang memberi pengertian khamar dengan lebih menonjolkan unsur yang memabukkan. Artinya, segala sesuatu yang memabukkan disebut khamar. Quraish Shihab dalam Tafsir al-Misbah mendefinisikan "khamar adalah segala sesuatu yang memabukkan, apapun bahan mentahnya.

${ }^{\delta}$ Disampaikan pada kegiatan Sosialisasi Halal Haram Pangan, pada tanggal 27 November 2013 di Aula Hotel Palapa Tarutung Tapanuli Utara

${ }^{\circledR}$ Penulis adalah Kepala MTs Al-Falah Tarutung dan juga merupakan Ketua Umum MUI Kabupaten 
Minuman yang berpotensi memabukkan bila diminum dengan kadar normal oleh seorang normal, baik banyak maupun serta baik ia diminum memabukkan secara faktual atau tidak".

Dari paparan di atas diketahui bahwa penggunaan kata 'arak' sebagai terjemahan dari kata 'khamar' adalah bersifat temporal, yaitu kata yang merujuk kepada sesuatu yang berlaku pada suatu saat atapun tempat, sedangkan di saat atau tempat yang lain penggunaan kata tersebut kurang layak digunakan lagi. Seperti kata 'sayyarah' dalam surah Yusuf ayat 19 tidaklah mungkin diterjemahkan dengan kata 'mobil' seperti makna yang berlaku saat ini, namun lebih layak diterjemahkan dengan 'musafir' sesuai dengan saat itu.

Berdasarkan beberapa definisi etimologi dan terminologi di atas dapat disimpulkan bahwa khamar merupakan segala zat yang dapat menutupi dan menghilangkan kesadaran diri baik berupa berbentuk minuman maupun makanan. Dalam tradisi arab kuno khamar biasa disebut juga dengan "ummu alkhabaits" yang artinya biang keburukan yang dilakukan di luar kendali kesadaran. Dengan landasan definisi ini dapat dinyatakan bahwa arak adalah (pasti) khamar, namun khamar belum tentu arak

\section{Tahap Pengharaman Khamar}

Amar haramnya konsumsi khamar bukanlah datang dalam satu proses atau tahap, namun membutuhkan proses yang panjang. Hal ini disebabkan perubahan suatu tradisi ke tradisi yang lain bukanlah suatu hal gampang segampang membalikkan tangan.

Setidaknya ada tiga proses yang masyhur dalam pengharaman khamar, namun pada uraian ini disampaikan empat proses untuk sebagai tambahan keilmuan dan wacana, bukan dalam rangka melemahkan pendapat para ulama terdahulu. Adapun proses pengharaman tersebut adalah sebagai berikut :

1. Surah al-Nahl ayat 67 (Proses Perenungan)

Dan dari buah kurma dan anggur, kamu buat minuman yang memabukkan dan rezeki yang baik. Sesungguhnya pada yang demikian itu benar-benar terdapat tanda (kebesaran Allah) bagi orang yang memikirkan. (An-Nahl : 67)

Kurma dan anggur adalah komoditas ekonomi jazirah arab, sejak dahulu kala. Komoditi tersebut selain diperdagangkan secara natural (alami) juga diolah menjadi minuman yang memabukkan. Seperti halnya buah aren bisa diolah menjadi tuak yang memabukkan atau menjadi gula merah yang digunakan dalam berbagai keperluan rumah tangga.

Dalam ayat ini Allah menyatakan secara tersirat bahwa dari kedua buah tersebut dapat diolah menjadi rezeki yang baik (perdagangan alami) dan hal yang tidak baik (minuman yang memabukkan)

2. Surah al-Baqarah ayat 219 (Proses Informasi)

Mereka bertanya kepadamu tentang khamar dan judi. Katakanlah: "Pada keduanya itu terdapat dosa besar dan beberapa manfaat bagi manusia, tetapi dosa keduanya lebih besar dari manfaatnya". (AlBaqarah: 219)

Ayat ini turun disebabkan oleh Umar bin Khattab beserta para sahabat yang lain bertanya kepada Rasulullah SAW perihal minuman yang memabukkan dan menghilangkan akal. 
Dalam masyarakat kita saat ini, bahkan bagi orang barat sekali pun kalau ditanya secara jujur tentang manfaat dari miras akan didapatkan jawaban bahwa miras itu menimbulkan problem-problem sosial yang bersifat negatif bahkan destruktif.

Maka pertanyaan beberapa sahabat ini menunjukkan munculnya kesadaran sosial bahwa di dalam efek khamar terdapat hal-hal yang tidak baik dalam masyarakat.

\section{Surah al-Nisa ayat 43 (Proses Pengharaman Temporer)}

Hai orang-orang yang beriman, janganlah kamu shalat, sedang kamu dalam keadaan mabuk, sehingga kamu mengerti apa yang kamu ucapkan, ..... (al-Nisa:43)

Ayat ini turun disebabkan oleh kesalahan imam membaca surat al-Kafirun secara keliru disebabkan pengaruh khamar.

Dari ayat di atas disimpulkan bahwa konsumsi khamar masih dibolehkan dengan batasan tidak boleh mendirikan salat kalau sedang mabuk, dan juga dibolehkan minum khamar selama selama tidak menghilangkan kesadaran diri.

\section{Surah al-Maidah ayat 90 (Proses Pengharaman Total)}

Hai orang-orang yang beriman, sesungguhnya (meminum) khamar, berjudi, (berkorban untuk) berhala, mengundi nasib dengan panah, adalah perbuatan keji termasuk perbuatan setan. Maka jauhilah perbuatan-perbuatan itu agar kamu mendapat keberuntungan (al-Maidah: 90)

Pada ayat ini, Allah SWT menyatakan bahwa khamar merupakan perbuatan syaitan yang harus dijauhi. Penggunaan kata 'jauhi' adalah sebagai simbol pengharaman secara halus sehingga tidak terbersit niat untuk mengkonsumsinya.

\section{Khamar dan Alkohol}

Khamar pasti mengandung alcohol (etanol), namun tidak setiap sesuatu yang beralkohol adalah khamar. Inilah yang menjadi perdebatan para ulama dan para ilmuwan (saintis) dalam penetapan hukum alkohol.

Sebagaimana diketahui bahwa bukan hanya unsur alkohol saja yang dapat membuat manusia kehilangan kesadaran namun alkohol bukan satu-satunya senyawa kimia yang dapat menyebabkan mabuk, banyak senyawa-senyawa lain yang terdapat pada minuman keras yang bersifat memabukkan jika diminum dalam kadar cukup tinggi. Secara umum, golongan alkohol bersifat narkosis (memabukkan), demikian juga komponen-komponen lain yang terdapat pada minuman keras seperti aseton, ester dan lainlain. Secara umum, senyawa-senyawa organik mikromolekul dalam bentuk murninya kebanyakan adalah racun. Oleh karena itu, tidak dapat ditentukan keharaman sesuatu hanya dari alkoholnya saja.

Jika yang diharamkan adalah alkoholnya, maka dampaknya akan sangat luas sekali karena banyak sekali makanan dan minuman yang mengandung alkohol, baik terdapat secara alami (sudah terdapat sejak bahan pangan tersebut baru dipanen dari pohon) seperti pada buah-buahan, atau terbentuk selama pengolahan seperti kecap. Akan tetapi kita mengetahui bahwa buah-buahan segar dan kecap tidak meyebabkan mabuk. Mengapa golongan yang mengharamkan alkohol masih mengkonsumsi buah-buahan yang pada hakikatnya mengandung alkohol?. 
Hal ini dapat dibuktikan bahwa juice jeruk segar mengandung alkohol sebesar $0.15 \%$ dan begitu juga dengan buah-buahan lainnya yang berbeda kadar alkoholnya. Namun bukan berarti buah tersebut haram untuk dikonsumsi. Hal ini berdasarkan sabda Rasulullah Saw :

1. Minumlah itu (jus) selagi ia belum diambil syaitan (beralkohol). Sahabat-sahabat bertanya: Berapa lama ia akan terjadi? dalam tiga hari, jawab Nabi. (Hadis Ahmad diriwayatkan dari Abdullah bin Umar).*

2. Bahwa lbnu Abbas pernah membuat jus untuk Nabi saw. Nabi meminumnya pada hari itu, besok dan lusanya hingga sore hari ketiga. Setelah itu Nabi menyuruh khadam (pelayan) menumpahkan dan memusnahkannya. (Hadis Muslim berasal dari Abdullah bin Abas). ${ }^{\dagger}$

Dengan kata lain, juice buah-buahan dapat berubah menjadi khamar jika didiamkan lebih dari 3 malam. Begitu juga halnya dengan tape yang mengandung alkohol. Dalam Penelitian tape ketan yang dilaporkan pada jurnal ilmiah International Journal of Food Sciences and Nutrition tahun 2001 bahwa kadar alkohol tape dapat naik sampai dengan 3\% jika didiamkan selama tiga hari. Proses naiknya kadar alkohol tape dalam penelitian tersebut adalah sebagai berikut :

1. Kadar alkohol (\%) pada 0 jam fermentasi tidak terdeteksi,

2. setelah 5 jam fermentasi kadar alkoholnya $0.165 \%$,

3. setelah 15 jam $0.391 \%$,

4. setelah 24 jam $1.762 \%$,

5. setelah 36 jam $2.754 \%$,

6. setelah 48 jam $2.707 \%$

7. setelah 60 jam $3.380 \%$.

Dari data tersebut terlihat bahwa setelah fermentasi 1 hari saja kadar alkohol tape telah mencapai $1.76 \%$, sedangkan setelah 2.5 hari (60 jam) kadarnya menjadi $3.3 \%$, bisa dibayangkan jika dibiarkan terus beberapa hari, bisa mencapai berapa \%?

Dari paparan di atas timbul pertanyaan, bagaimana cara menentukan tingkat keharaman dan kehalalan atas makanan dan minuman yang mengandung alkohol?. Majelis Ulama Indonesia telah lama mengkaji masalah alkohol (etanol) ini. Pada tahun 1993 MUI mengadakan muzakarah Nasional tentang alkohol dalam minuman dengan mempertemukan para ulama dan ilmuwan untuk membahas status kehalalan alkohol. Pada saat itu telah disepakati bahwa yang diharamkan adalah minuman beralkohol atau minuman keras, bukan alkohol (etanol)nya itu sendiri. Akan tetapi, apabila sesuatu sudah masuk kedalam kategori minuman beralkohol maka berapapun kadar alkoholnya (etanolnya) tetap saja haram. Setelah muzakarah, ternyata diantara para ulama dan ilmuwan masih terdapat perbedaan pendapat, apakah minuman beralkohol haram atau alkohol (etanol) juga haram. Oleh karena itu, MUI terus melakukan kajian sehingga pada bulan Agustus 2001, komisi fatwa MUI mampu memutuskan bahwa minuman keras adalah minuman yang mengandung alkohol (etanol) minimal satu persen.

Dengan adanya hasil ijtihad ini maka semakin kuatlah pendapat bahwa yang diharamkan itu bukan karena keberadaan etanol (alkohol) dalam bahan pangan semata, akan tetapi lebih kepada berapa kadarnya. Adanya batas $1 \%$ ini akan sangat memudahkan dalam penetapan status kehalalan minuman

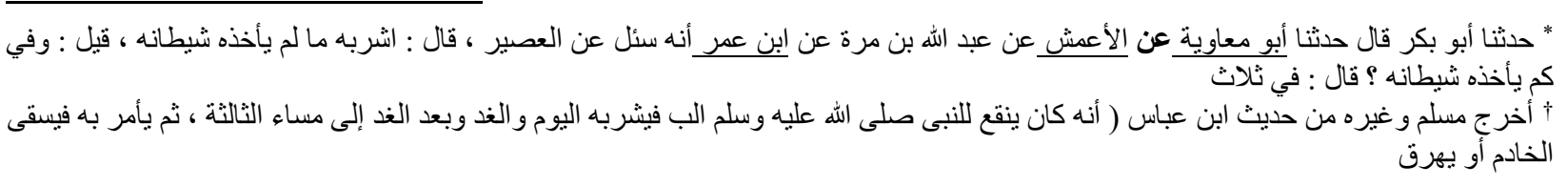


dan minuman. Minuman ataupun makanan yang mengandung alkohol (etanol) sebanyak $1 \%$ atau lebih masuk kedalam golongan khamar. Namun perlu dingat, minuman dan minuman yang mengandung alkohol (etanol) dibawah 1\% tidak otomatis halal karena untuk menetapkannya harus dilihat bahan-bahan yang digunakan dan cara pembuatannya. Sebagai contoh, minuman Shandy mengandung etanol kurang dari $1 \%$, akan tetapi minuman ini terbuat dari bir dimana bir masuk kedalam kategori minuman keras sehingga masuk kedalam golongan khamar. Dengan demikian, minuman Shandy jelas haram karena terbuat dari khamar yang diencerkan, sesuai dengan kaidah "jika banyaknya memabukkan maka sedikitnya pun haram". Oleh karena itu jelaslah bahwa kehalalan suatu bahan pangan bukan ditentukan oleh ada atau tidaknya etanol atau alkohol, akan tetapi ditentukan oleh berapa banyak etanol yang terkandung disamping, tentu saja, adanya bahan-bahan haram lainnya dan cara pembuatannya.

\section{E. Khamar dan Alkohol di Persimpangan Paradigma Haram atau Najis}

Pola fikir manusia yang berbeda-beda terkadang telah mempersempit pemaknaan atas suatu hal yang -terkadang- justru membuatnya terjebak dalam kebingungan dan kerancuan dalam perbuatan. Contoh di antara hal tersebut adalah kekaburan persepsi atas makna kata haram dan najis.

Jika dikaji dari sudut pandang yurisprudensi Islam, kata 'haram' identik dengan kata 'tidak boleh' yang langsung berkaitan dengan balasan 'dosa' dan 'pahala'. Sedangkan kata 'najis' atau 'najasah' indentik dengan kata 'taharah' atau bersuci. Di sisi lain, kata 'haram' merupakan status hukum atas perbuatan maupun perkataan, sedangkan 'najis' adalah status sifat atas suatu benda. Kedua kata ini sangat berbeda, namun dalam paradigma kaum muslimin terkadang hal tersebut disamakan.

Dapat dikatakan secara tegas bahwa segala yang najis itu pasti haram, namun sesuatu yang haram belum tentu najis. Contohnya adalah kotoran manusia ataupun hewan yang merupakan najis tentu hal itu haram untuk dikonsumsi, namun haramnya mengkonsumsi semut atau hewan buas apakah menjadikannya sebuah najis?.

Senada dengan hal di atas, khamar yang sudah dipastikan keharamannya telah menjadi perdebatan panjang di antara ulama maupun fuqaha tentang kenajisannya. Dalam hal ini ada dua pendapat yaitu pendapat yang menyatakan khamar adalah najis dan yang kedua menyatakan khamar bukanlah najis.

Pendapat yang pertama menyatakan bahwa khamar itu adalah najis adalah merupakan pendapat jumhur ulama, di antaranya adalah imam mazhab yang empat, dan pendapat ini dipilih oleh shaikhul Islam Ibnu Taimiyah. Alasan para ulama tersebut adalah firman Allah SWT dalam surah al-Maidah ayat 50.

Menurut mereka, maksud kata 'rijs' pada ayat tersebut adalah membawa najis. Dengan demikian, mereka menyatakan bahwa najisnya arak itu termasuk kategori najis hissiyah (najis yang dapat dirasakan dengan pancaindera).

Pendapat kedua, khamar itu suci (tidak najis). Ini adalah pendapat Rabi'ah, al-laits, al-Muzani, dan selainnya dari kalangan salaf. Dan ini adalah pendapat yang dipilih oleh asy-Syawkani, ash-Shan'ani, Ahmad Syakir, dan al-Albani rahimahullah. Para ulama ini mempunyai alasan sebagai berikut:

1. Tidak ada keterangan dalam ayat tersebut yang menunjukkan najisnya khamar. Sedangkan kata 'rijs; mengandung arti yang sangat banyak selain bermakna najis ia juga dapat bermakna kotoran, keburukan, siksaan, kufur, dosa dan lain-lain. 
2. Ayat-ayat yang menunjukkan pengharaman khamar tidak satu pun menunjukkan kenajisannya, tetapi benda yang najis sudah pasti adalah benda yang haram, dan benda yang haram belum tentu ia membawa maksud kepada najis secara fisik.

3. Kata rijs pada ayat tersebut diikat dengan perkataan "termasuk amalan syaitan". Dengan demikian, hal tersebut merupakan rijs amali (perbuatan yang najis), yang berarti sangat buruk, diharamkan atau dosa. Bukanlah berarti najis 'aini, sehingga dijadikan dasar meletakkan kedudukan (hukum) benda-benda yang disebutkan dalam ayat tersebut sebagai najis.

4. Hadist dari Anas radhiyallahu 'anhu, "Rasulullah memerintahkan seseorang untuk mengumumkan: "Ketahuilah sesungguhnya khamar telah diharamkan." "Aku pun keluar rumah dan menumpahkannya sehingga mengalir di jalan-jalan kota Madinah." (Hadis Riwayat Bukhari, 2332. Muslim, 1980)‡

Dari hadits tersebut diketahui bahwa para shahabat menumpahkan khamar mereka di jalan-jalan ketika khamar telah diharamkan. Ini menunjukkan bahwa khamr bukan najis, karena jalan-jalan yang dilewati kaum muslimin tidak boleh dijadikan tempat pembuangan najis. Bila ditanyakan: "Apakah hal itu dengan sepengetahuan Rasulullah Saw.?" Maka dapat dijawab: Jika Rasulullah mengetahuinya berarti hal itu dengan persetujuan beliau. Bila tidak diketahui oleh beliau, maka sesungguhnya Allah SWT. mengetahuinya, dan Allah tidak mungkin membiarkan ini terjadi bila memang hal itu adalah suatu kemungkaran, karena waktu itu merupakan masa turunnya wahyu

5. Hadits Ibnu 'Abbas r.a. yang diriwayatkan oleh Al-Imam Muslim dalam Shahih-nya, bahwa seorang laki-laki menghadiahkan sebuah wadah berisi khamar kepada Rasulullah Saw. Kemudian beliau berkata: "Tidakkah engkau mengetahui bahwa khamr telah diharamkan?" Kemudian ada seseorang yang membisiki laki-laki tersebut untuk menjualnya. Maka Rasulullah bersabda:"Sesungguhnya Dzat Yang mengharamkan untuk meminumnya juga mengharamkan untuk menjualnya." Kemudian Ibnu 'Abbas berkata: "Maka lelaki itu membuka wadah khamr tersebut dan menumpahkan isinya hingga habis."§ Kejadian ini disaksikan oleh Rasulullah Saw dan beliau tidak memerintahkan kepada-nya untuk mencuci wadah tersebut. Ini menunjukkan bahwa khamar tidaklah najis

6. Kaidah yang menyatakan yang hukum asal setiap sesuatu itu adalah suci. Tidak dapat dipindahkan hukumnya kecuali dengan dalil yang sahih. Dalam hal ini tidak ada dalil yang menunjukkan kenajisan khamar, maka tetaplah ia pada hukum asalnya.

Dengan landasan ini dapat disimpulkan bahwa najis tidaknya khamar tetap merupakan hasil ijtihad ulama dan bukan merupakan pernyataan langsung dari Allah SWT. maupun Rasulullah Saw. yang hukumnya bersifat qat'i (pasti). Namun bagaimana dengan hukum zat alkohol yang merupakan kandungan khamar?

Sebagaimana pada uraian tentang khamar, demikian halnya berkaitan dengan alkohol bahwa tiada satu dalilpun yang menyatakan bahwa alkohol itu adalah najis kecuali alkohol tersebut dibuat dari zat yang

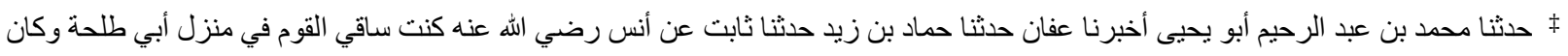

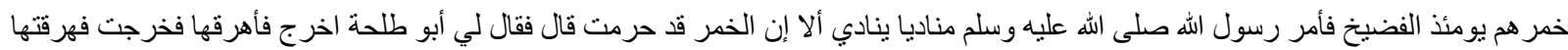
فجرت في سكاك المدينة

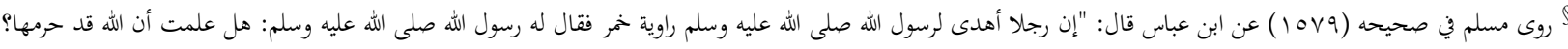

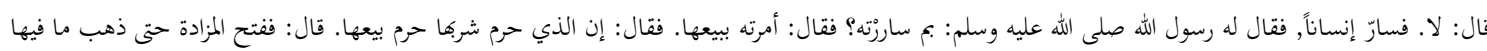


memang dasar hukumnya haram. Namun jika memang ada golongan yang menyatakan bahwa alkohol itu merupakan najis, maka tentunya seluruh buah-buahan akan haram untuk dikonsumsi.

\section{F. Penutup}

Dari ulasan problematika pemahaman tentang khamar dapat diambil simpulan bahwa :

1. Kata 'khamar' selayaknya diartikan dengan arti yang sebenarnya yaitu sebagai segala sesuatu yang membuat hilangnya kesadaran seseorang sehingga tidak terkontrol baik dalam perbuatan maupun perkataan dan tidak terbatas pada minuman saja.

2. Proses pengharaman khamar tidaklah sekaligus namun setidaknya ada empat tahap yang dilalui yaitu, proses perenungan, proses informasi, proses pengharaman temprorer dan proses pengharaman total.

3. Haramnya khamar yang berbentuk minuman bukanlah terfokus pada zat alkohol yang dikandungnya namun efek hilangnya kesadaran seseorang yang disebabkan kadar alkohol yang terlalu tinggi, karena buah-buahan juga mengandung alkohol namun tidaklah haram

4. Makanan dan minuman yang mengandung kadar alkohol di bawah $1 \%$ belum termasuk kategori khamar, namun perlu pengkajian dari berbagai aspek dari bahan baku hingga proses pembuatan sehingga mencapai kesimpulan halal.

5. Kenajisan khamar masih tetap dalam perselisihan, namun yang paling kuat adalah khamar bukanlah najis karena ketiadaan dalil yang menyatakannya sebagai najis.

6. Khamar dalam bentuk minuman/makanan mengandung alkohol namun alkohol tidaklah selalu berada pada khamar.

Walhamdulillah

Innahu wa rasulahu 'alam 